\title{
BLENDED METHOD: ONLINE-OFFLINE TEACHING AND LEARNING, ON STUDENTS' READING ACHIEVEMENT
}

\author{
Harits Setyawan \\ Institut Teknologi Sumatera (ITERA) \\ harits.setyawan@staff.itera.ac.id
}

\begin{abstract}
This study aimed at investigating the effect of Blended Method (online and offline teaching and learning) and Traditional Method (offline teaching and learning), as the comparison, on students' reading achievement. There were 200 college students involved in this study. Half of them were taught through a blended teaching method and half of them were taught through a traditional teaching method. The data were taken from the students' final scores in the lectures which included scores of assignment, quiz, mid-term test, and final term test. The final scores of the two groups were compared to find out the effect of the blended teaching method and the traditional teaching method. The result showed that the scores of students who were taught through Blended Method were significantly better than the scores of students who were taught through Traditional Method. It indicates that utilizing new methods while maintaining good aspects of pre-existing methods has a positive impact on students' achievement.
\end{abstract}

Key words: blended method, traditional method, reading achievement

\section{A. INTRODUCTION}

Technological developments encourage learning methods to change from traditional learning methods into methods which are considered more modern. Bakia, Shear, Toyama, \& Lasseter (2012: 1) state "the available evidence suggests that schools are using information technologies with the intention of expanding access, improving instructional quality, and reducing costs associated with traditional instruction". One of the learning methods born because of technological developments is online teaching and learning. UMass Faculty (2003: 5) defines online teaching and learning as "faculty-delivered instruction via the Internet. Online instruction includes real-time (synchronous) and anytime, anywhere (asynchronous) interactions". Furthermore, Means, Toyama, Murphy, Bakia, \& Jones (2010: 1) explain “one class of online learning models uses asynchronous communication tools (e.g., e-mail, threaded discussion boards, newsgroups) to allow users to contribute at their convenience. Synchronous 
technologies (e.g., webcasting, chat rooms, and desktop audio/video technology) are used to approximate face-to-face teaching strategies such as delivering lectures and holding meetings with groups of students".

With the offered features, online teaching and learning are very promising for improving the quality of education. Patrick \& Powell (2009: 9) state "online learning has the potential to transform teaching and learning by redesigning traditional classroom instructional approaches, personalizing instruction and enhancing the quality of learning experiences". Online teaching and learning offer not only education quality improvement but also a solution to the problems faced by traditional teaching and learning. Means, Toyama, Murphy, Bakia, \& Jones (2010: 1) explain "with the advent of the Internet and the World Wide Web, the potential for reaching learners around the world increased greatly, and today's online learning offers rich educational resources in multiple media and the capability to support both real-time and asynchronous communication between instructors and learners as well as among different learners". In line with the statement, Keng (2018: 89) argues "increasing globalization and the growing body of Web-based technologies together have blurred cultural and national boundaries. In other words, national culture and national borders no longer pose a barrier to the collaboration of learners across cultures".

Not only there, online teaching and learning also provide facilities for both students and institutions which traditional teaching and learning do not. Xu \& Jaggars (2013: 23) explain "from the student perspective, the convenience of online learning is particularly valuable to adults with multiple responsibilities and highly scheduled lives; thus, online learning can be a boon to workforce development, helping adults to return to school and complete additional education that otherwise could not fit into their daily routines. From an institutional perspective, online modalities allow colleges to offer additional courses or course sections to their students, increasing student access to (and presumably progression through) required courses". Furthermore, Means, Toyama, Murphy, Bakia, \& Jones (2010: 1) explain “online learning has become popular because of its potential for providing more flexible access to content and 
instruction at any time, from any place. Frequently, the focus entails (a) increasing the availability of learning experiences for learners who cannot or choose not to attend traditional face-to-face offerings, (b) assembling and disseminating instructional content more cost efficiently, or (c) enabling instructors to handle more students while maintaining learning outcome quality that is equivalent to that of comparable face-to-face instruction".

Apart from the strengths, however, online teaching and learning also have some weaknesses which then cause a debate whether or not the method is suitable for certain types of learning. Nguyen (2015: 316) states "online learning is a story that is still being written, and how it progresses will likely depend on those present". Some researchers argue that traditional teaching and learning are still a powerful teaching and learning method. Swan (2003: 11) argues “teachers' verbal immediacy behaviors (i.e., giving praise, soliciting viewpoints, humor, selfdisclosure) and their non-verbal immediacy behaviors (i.e., physical proximity, touch, eyecontact, facial expressions, gestures) can lessen the psychological distance between teachers and their students, leading to greater learning". Research also proves the ineffectiveness of online teaching and learning. Ni (2013: 211) states "student grade distribution does not present significant differences between online and face-to-face classes in this study". In line with the statement, Jabeen \& Thomas (2015: 1) state "the students find learning with an instructor to be a lot more effective than learning alone in an online environment. They prefer classroom environment more than the online setting for language learning". Furthermore, online teaching and learning also bring a problem to the lecturers and students. Academic Partnerships (2012: 12) state "online environments offer for flexibility in assessment, but if not managed well, this flexibility can create problems of security and authentication”. More severely, Jaggars \& Bailey (2010: 11) argue "for low-income and underprepared students, however, an expansion of online education may not substantially improve access and may undercut academic success and progression through school".

Applying online teaching and learning to answer the challenges of the times without eliminating the need for face-to-face classes might become the solution which bridges two conflicting 
groups regarding to the application of online teaching and learning. It, however, needs proof through a number of studies. Therefore, this study which was entitled Blended Method: OnlineOffline Teaching and Learning, on Students' Reading Achievement was accordingly conducted.

\section{B. METHOD}

\section{Design of the Research}

In this paper, used qualitative research. This research compared the students' reading achievements between those who were taught through the blended method (online and offline) and those who were taught through the traditional method (offline). Thus, there were two groups in this research whose scores were compared to find out the effect of the blended method: online-online teaching and learning on students' reading achievements. These students were taught for a semester and their final scores at the end of the semester were the data used for comparison. The data were then statistically calculated to find out the effects of both blended and traditional methods on the students' reading achievements.

\section{Population and Sample}

Population is the large group about which the generalization. And creswell states sample is subgroup of the target population. The population of this research was the first year students of Institut Teknologi Sumatera (ITERA). Half of the first year students took Critical Reading course at the first semester and half of them took Critical Reading course at the second semester. The samples of this research were students who took Critical Reading course at the first semester. The total number of the samples was 200 students. Half of them were taught through the Blended Method (online-offline) and half of them were taught through the Traditional Method (offline).

\section{Procedures of the Research}

Students who were taught through the Blended method had to access Critical Reading online course every week. In the course there were weekly topics. In each of the topics, there were Forum, Quiz, and Assignment. In Forum, the students were required to discuss the ongoing topic with other students. It is a must that Forum was marked Completed since the students could not 
access Quiz if it was not completed. In Quiz, the students had 15 minutes to answer 5 questions. The passing grade of the quiz was 60 with unlimited attempts. It was also a must that Quiz was marked completed since the students could not access the next topic if the previous quiz was not marked completed. In Assignment, the students were required to upload weekly assignments. The assignments were either group or individual assignments. If the students missed a topic in the online course, they had to meet the lecturer for access to the next topic. Besides following the online course, the students also had to attend face-to-face classes of Critical Reading course every week. In other words, this group was taught through Collaborative and Traditional approach. Epignosis LLC (2014: 71) explains "Collaborative learning is an e-learning approach where students are able to socially interact with other students, as well as instructors. In essence, learners work together in order to expand their knowledge of a particular subject or skill. In e-learning environments, this is typically done through live chats, message boards, or instant messaging”.

Students who were taught through the Traditional method did not access Critical Reading online course. They attended only face-to-face classes of Critical Reading course every week. Activities which the students who were taught through Traditional method did in the class were the same with activities which the students who were taught through Blended method did in the class. The only difference was that those who were taught through Blended method joined Critical Reading online course but those who were taught through Traditional method did not.

\section{Data Collecting Instruments}

The data were collected by using tests and assignments which involved Assignment, Quiz, Mid Term Test, and Final Term Test. Tests and assignments which were given to both groups were the same. When all scores had been accomplished, the final scores between those who were taught through Blended method (online-offline) and those who were taught through Traditional method (offline) were compared.

\section{Data Analysis}


The data were statistically analyzed to find out the effect of both Blended and Traditional methods on students' reading achievements.

\section{RESULT}

Having analyzed the collected data, the researcher found that both students taught through Blended Method and students taught through Traditional Method got scores which varied into A, B, C, D, and E. The following pie charts show the distribution of the students' scores.

Pie Chart 1: The Score Distribution of Students Taught through Blended Method.

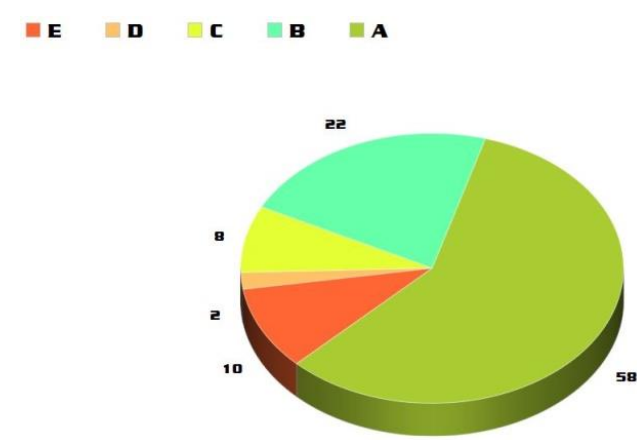

In the class which students were taught through Blended Method, there were 58 students who got A, 22 students who got B, 8 students who got C, 2 students who got $\mathrm{D}$, and 10 students who got E. The highest percentage was occupied by score A with $58 \%$ of the overall number of students, while the smallest percentage was occupied by score D with only $2 \%$ of the overall number of students. 
Pie Chart 2: The Score Distribution of Students Taught through Traditional Method.
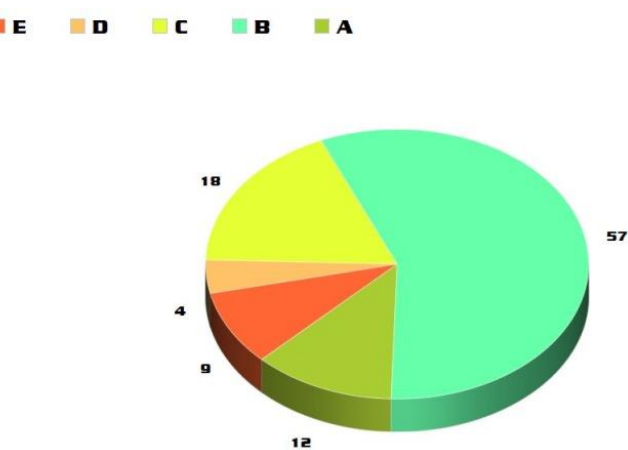

In the class which students were taught through Traditional Method, there were 12 students who got A, 57 students who got B, 18 students who got C, 4 students who got D, and 9 students who got E. The highest percentage was occupied by score B with $57 \%$ of the overall number of students, while the smallest percentage was occupied by score D with only $4 \%$ of the overall number of students.

To find out the mean of both groups' scores and if there was a significant difference in reading achievement between students who were taught through Blended Method and students who were taught through Traditional Method, the collected data were statistically calculated. The following tables show the results of statistical calculation.

\begin{tabular}{|c|c|c|c|c|c|}
\hline & Group & $\mathrm{N}$ & Mean & Std. Deviation & Std. Error Mean \\
\hline \multirow[t]{2}{*}{ Score } & 1 & 100 & 81.60 & 12.770 & 1.277 \\
\hline & 2 & 100 & 75.90 & 10.550 & 1.055 \\
\hline
\end{tabular}

Table 1 shows that there were 200 students involved in this research. They were divided into two groups: group 1 and group 2. Students who were taught through Blended Method were in group 1, while students who were taught through Traditional Method were in group 2. Each of 
the group consisted of 100 students. From the table, it is discovered that the final score mean of group 1 is 81.60 and the final score mean of group 2 is 75.90 . The following table shows whether or not there is a significant difference between the two groups' reading achievements.

\begin{tabular}{|c|c|c|c|c|c|c|c|c|c|c|}
\hline & & \multicolumn{2}{|c|}{$\begin{array}{c}\text { Levene's Test for } \\
\text { Equality of Variances }\end{array}$} & \multicolumn{7}{|c|}{ t-test for Equality of Means } \\
\hline & & \multirow[b]{2}{*}{$\mathrm{F}$} & \multirow[b]{2}{*}{ Sig. } & \multirow[b]{2}{*}{$\mathrm{t}$} & \multirow[b]{2}{*}{ df } & \multirow{2}{*}{$\begin{array}{l}\text { Sig. }(2- \\
\text { tailed) }\end{array}$} & \multirow{2}{*}{$\begin{array}{c}\text { Mean } \\
\text { Difference }\end{array}$} & \multirow{2}{*}{$\begin{array}{l}\text { Std. Error } \\
\text { Difference }\end{array}$} & \multicolumn{2}{|c|}{$\begin{array}{c}\text { 95\% Confidence } \\
\text { Interval of the } \\
\text { Difference }\end{array}$} \\
\hline & & & & & & & & & Lower & Upper \\
\hline \multirow[t]{2}{*}{ Score } & $\begin{array}{l}\text { Equal variances } \\
\text { assumed }\end{array}$ & 2.518 & .114 & 3.441 & 198 & .001 & 5.700 & 1.656 & 2.434 & 8.966 \\
\hline & $\begin{array}{l}\text { Equal variances not } \\
\text { assumed }\end{array}$ & & & 3.441 & 191.194 & .001 & 5.700 & 1.656 & 2.433 & 8.967 \\
\hline
\end{tabular}

Table 2 shows the Sig. value .114 is greater than .005 (Sig.114 >.005). It means that the variability in the two groups is about the same. In other words, scores in group 1 (students taught through Blended Method) do not vary too much from scores in group 2 (students taught through Traditional Method). The scores of both groups similarly vary into A, B, C, D, and E. Furthermore, the Sig. (2-tailed) value .001 is less than .005 (Sig. 2-tailed .001<.005). It means that there is statistically significant difference in students' reading achievements between the two groups. In other words, students who were taught through Blended Method got significantly better achievement than students who were taught through Traditional Method.

\section{DISCUSSION}

Having statistically calculated the data, the researcher found that students who were taught through Blended Method got significantly better achievement than students who were taught through Traditional Method. Align with this finding, Means, Toyama, Murphy, \& Bakia (2013: 35) state "in recent applications, purely online learning has been equivalent to face-to-face instruction in effectiveness, and blended approaches have been more effective than instruction offered entirely in face-to-face mode". 
The finding of this research indicates that utilizing new methods while maintaining good aspects of pre-existing methods has a positive impact on students' achievement. The blended method in this research was the combination of both online and offline teaching-learning. It answered the challenges of technology growth through applying online teaching and learning without abandoning the fact that offline or traditional methods had their own strengths, such as the stability, the security, and most importantly the teachers. As Sun \& Chen (2016: 171) explain, "teachers definitely and indisputably play a crucial role in online education. They facilitate individual and group discussions, respond to student questions, design course assignments, and evaluate students' learning".

Online teaching and learning indeed have weaknesses. When the electricity is off or when the network is down, it will be difficult to access online courses. Online teaching and learning also need internet connection. In other words, students and teachers need to spend money for the internet connection if they do not access the courses at campus. Furthermore, when the students do an online test, the teacher cannot feel fully sure if the students themselves who do the test, not someone else. However, it does not mean that online teaching and learning do not have advantages. Lack (2013: 14) explains "the consistency of findings in even imperfect studies of learning outcomes suggests that determined efforts should be made to improve online learning, taking full advantage of features that are specific to an online environment, such as automatic and interactive feedback loops".

Worry about a change is normal. Some people prefer the traditional method, some prefer the online method, and the others combine the two methods. "Providing training is one way to reduce resistance by faculty to participate in online courses (Mansour \& Mupinga, 2007: 246)". Although online teaching and learning do not seem to be wholeheartedly accepted by some people, the advantages might give a major breakthrough in the education world. 


\section{E. REFERENCES}

Academic Partnerships. (2012). A Guide to Quality in Online Learning. California: Creative Commons.

Bakia, Shear, Toyama, \& Lasseter. (2012). Understanding the Implications of Online Learning for Educational Productivity. Washington: U.S. Department of Education.

Jaben \& Thomas. (2015). Effectiveness of Online Language Learning. Proceedings of the World Congress on Engineering and Computer Science 2015. Vol I, WCECS 2015, October 21-23, 2015, San Francisco, USA

Jaggars \& Bailey. (2010). Effectiveness of Fully Online Courses for College Students: Response to a Department of Education Meta-Analysis. Community College Research Center. Teachers College, Columbia University.

Epignosis LLC. (2014). E-Learning: Concepts, Trends, Applications. California: Epignosis LLC.

Keng. (2018). Comparing the Cultural Dimensions and Learners' Perceived Effectiveness of Online Learning Systems (OLS) among American and Malaysian Learners. International Journal of Computer Science \& Information Technology (IJCSIT), Vol. 10, No. 1.

Lack. (2013). Current Status of Research on Online Learning in Postsecondary Education. United States: ITHAKA S+R.

Mansour \& Mupinga. (2007). Students' Positive and Negative Experiences in Hybrid and Online Classes. Coll Stud. Vol. 41, No. 1. 
Matsunaga. (2016). College Students' Perceptions of Online Learning: Knowledge Gain and Course Effectiveness. The Online Journal of Distance Education and e-Learning. Vol.4, Issue 2.

Means, Toyama, Murphy, \& Bakia. (2013). The Effectiveness of Online and Blended Learning: A Meta-Analysis of the Empirical Literature. Teachers College Record, Vol. 115, 030303.

Means, Toyama, Murphy, Bakia, \& Jones. (2010). Evaluation of Evidence-Based Practices in Online Learning: A Meta-Analysis and Review of Online Learning Studies. Washington: U.S. Department of Education.

Nguyen. (2015). The Effectiveness of Online Learning: Beyond No Significant Difference and Future Horizons. MERLOT Journal of Online Learning and Teaching. Vol. 11, No. 2.

Ni. (2013). Comparing the Effectiveness of Classroom and Online Learning: Teaching Research Methods. Journal of Public Affairs Education, Vol. 19 (2), 199-215.

Patrick \& Powell. (2009). A Summary of Research on the Effectiveness of K-12 Online Learning. iNACOL. June 2009.

Sun, A., \& Chen, X. (2016). Online education and its effective practice: A research review. Journal of Infor-mation Technology Education: Research, 15, 157-190. Retrieved from http://www.informingscience.org/Publications/3502

Swan, K. (2003). Learning effectiveness: what the research tells us. In J. Bourne \& J. C. Moore (Eds) Elements of Quality Online Education, Practice and Direction. Needham, MA: Sloan Center for Online Education, 13-45. 
UMass Faculty. (2003). Teaching and Learning Online: Communication, Community, and Assessment. Massachusetts: Massachusetts University.

Xu \& Jaggars. (2013). Examining the Effectiveness of Online Learning within a Community College System: An Instrumental Variable Approach. Community College Research Center. Teachers College, Columbia University. 